\title{
Subclinical ketosis risk prediction in dairy cows based on prepartum metabolic indices
}

\author{
[Previsão do risco de cetose subclínica em vacas de leite, baseado nos índices metabólicos pré-parto] \\ D. Wang, D. $Y u$, C. Zhao, C. Xia ${ }^{*}$, C. $X u$, L. $W u$ \\ Heilongjiang Bayi Agricultural University - Daqing, China
}

\begin{abstract}
Ketosis can seriously impair cow performance. This study detected changes in prepartum blood metabolic parameters for predicting postpartum ketosis occurrence in dairy cows. Body condition score (BCS) was assessed before and after delivery. Blood samples of 63 cows were collected from 10 days before calving to 10 days after calving to measure metabolic parameters including $\beta$-hydroxybutyric acid (BHBA), nonesterified fatty acid (NEFA), glucose (GLU), total bilirubin (TBIL), direct bilirubin (DBIL), indirect bilirubin (IBIL), total protein (TP), albumin (ALB), globulin (GLO), alanine aminotransferase (ALT), and aspartate aminotransferase (AST). There was a postpartum subclinical ketosis incidence of $42.25 \%$. Compared with prepartum, plasma, levels of BHBA, AST, and NEFA significantly increased postpartum, and prepartum AST $(R=0.57)$ and NEFA $(R=0.45)$ showed a significant positive correlation with ketosis postpartum. Plasma GLU level significantly decreased postpartum and was significantly negatively correlated with ketosis $(\mathrm{R}=-0.21)$. Receiver operating characteristic curve analysis revealed prepartum BSC $<2.88$, and prepartum plasma AST > 68.0 U/L, GLU <3.97mmol/L, NEFA > 0.27mmol/L, and BHBA > $0.43 \mathrm{mmol} / \mathrm{L}$, indicating a high risk of subclinical ketosis postpartum. These levels can be used as risk indicators to predict the occurrence of subclinical ketosis in postpartum cows.
\end{abstract}

Keywords: dairy cow, subclinical ketosis, ROC analysis

\section{RESUMO}

A cetose pode trazer sérios prejuízos ao desempenho da vaca. Este estudo detectou alterações nos parâmetros metabólicos do sangue pré-parto para prever a cetose pós-parto que ocorre em vacas leiteiras. $O$ escore de condição corporal (ECC) foi avaliado antes e após o parto. Foram coletadas amostras de sangue de 63 vacas entre 10 dias antes e 10 dias após o parto para medir os parâmetros metabólicos, incluindo ácido $\beta$-hidroxibutírico (BHBA), ácido graxo não esterificado (NEFA), glicose (GLU), bilirrubina total (TBIL), bilirrubina direta (DBIL), bilirrubina indireta (IBIL), proteína total (TP), albumina (ALB), globulina (GLO), alanina aminotransferase (ALT) e aspartato aminotransferase (AST). Houve uma incidência de cetose subclínica pós-parto de 42,25\%. Em comparação com o pré-parto, o plasma, os níveis de BHBA, AST e NEFA aumentaram significativamente no pós-parto, e AST no pré-parto $(R=0,57)$ e NEFA $(R=0,45)$ mostraram uma correlação significativa positiva com cetose pós-parto. $O$ nível plasmático de GLU diminuiu significativamente no pós-parto e foi negativamente correlacionado com a cetose de forma significativa $(R=-0,21)$. A análise da curva característica de operação do receptor revelou $B S C$ pré-parto <2,88 e AST plasmático pré-parto> 68,0 U / L, GLU <3,97mmol / L, NEFA> 0,27mmol / L e BHBA>0,43mmol / L, indicando um alto risco de cetose subclínica pós-parto. Esses níveis podem ser usados como indicadores de risco para prever a ocorrência de cetose subclínica em vacas no pós-parto.

Palavras-chave: vaca leiteira, cetose subclínica, análise ROC

Recebido em 9 de junho de 2020

Aceito em 18 de agosto de 2020

*Autor para correspondência (corresponding author)

E-mail:xcwlxyf2014@163.com 


\section{INTRODUCTION}

Ketosis is a common serious metabolic disease in the perinatal period. The intake of dry matter is reduced during early lactation and the demands for energy, fat, and protein are increased, so cows must mobilize their body fat to meet the needs for lactation. Thus, cows are prone to a negative energy balance (NEB) (Ježek et al., 2017). To adapt to the NEB, cows mobilize fat to provide free fatty acids as fuel. A significant amount of fatty acids enters the liver to disturb liver metabolism and produce a large amount of ketone bodies, thus causing ketosis (Gathercole et al., 2013). Currently, the accepted gold standard for diagnosing ketosis is $\beta$-hydroxybutyric acid (BHBA) levels in the plasma or serum (Carrier and Stewart, 2004). It is often divided into clinical ketosis and subclinical ketosis based on the presence or absence of clinical manifestations.

When the serum concentration of BHBA is $\geq$ $3.00 \mathrm{mmol} / \mathrm{L}$, it is determined as clinical ketosis, and subclinical ketosis when the concentration is 1.20-2.90mmol/L (Ospina et al. 2010; Vanholder et al., 2015). The incidence of clinical ketosis is $2-20 \%$ in high yield cattle in China and the incidence of subclinical ketosis generally exceeds $30 \%$ ( $\mathrm{Xu}$ et al., 2016). Subclinical ketosis is considered a predisposing factor for other metabolic and infectious diseases such as hysteritis, mastitis, and clinical ketosis, which cause significant economic damage in the dairy industry (Xu et al., 2016; Viña et al., 2016). In addition to the effects on disease events, subclinical ketosis has been found to decrease milk yield in early lactation (Mcart et al., 2012) and may adversely affect reproduction. However, subclinical ketosis has no obvious clinical symptoms, is difficult to prevent and diagnose, and is harmful to the health of dairy cows. Therefore, exploring early warning indicators and techniques for dairy cow ketosis is an important measure to improve the prevention efficiency of dairy cow ketosis.

Liver function is closely related to ketosis but the effectiveness of liver function biomarkers in predicting ketosis is unknown. The aims of the present study were to analyze the prepartum and postpartum blood indices (BHBA, glucose (GLU), non-esterified fatty acids (NEFA), and liver function indicators) in dairy cows and to determine specific early warning indicators for cow ketosis, thereby enhancing the effective monitoring of postpartum ketosis to facilitate early prevention.

\section{MATERIALS AND METHODS}

Experiments were conducted in an intensive dairy farm in Heilongjiang Province, China, using freestanding rails, total mixed ration feeding, and cattle farm management software (Afimilk 0418A09QPDX, Israel). All methods and animal care were performed in accordance with the relevant guidelines and regulations of the Institute of Animal Science, Chinese Academy of Agricultural Sciences. In order to reach a confidence interval of more than $90 \%$ when investigating the true incidence of cattle farms, 63 Holstein cows of similar age and gestational age were selected for tracking from 10 days before calving to 10 days after calving.

All cows are selected to be dairy cows, were 3-5 years old, with parity of $2-3$. The daily average milk production after delivery was $23.6 \mathrm{~kg} /$ day. All tested cows were examined by on-site veterinarians before blood collection, and the experimental cows had no recent disease. The study protocol was approved by the Ethics Committee on the Use and Care of Animals of Heilongjiang Bayi Agricultural University (number 010038/2018).

Among the randomly selected test cows $(n=63)$, blood samples $(10 \mathrm{ml})$ were collected intravenously from the coccygeal vein on the 10th day before delivery and the 10th day after delivery. The serum was dispensed at 5,000rpm. The collected serum was separated into prenatal and postnatal groups. The serum was dispensed and stored in a freezer at $-80^{\circ} \mathrm{C}$ until subsequent analyses.

The BHBA level was assayed using an ELISA kit (Randox Laboratories, UK). Levels of plasma GLU, NEFA, and the following parameters were assayed: total bilirubin (TBIL), direct bilirubin (DBIL), indirect bilirubin (IBIL), total protein (TP), albumin (ALB), globulin (GLO), alanine aminotransferase (ALT), and aspartate aminotransferase (AST). The blood biochemical parameters were detected using a biochemical kit (Roche Diagnostics, Shanghai, China) and a fully automatic biochemical analyzer (Synchron DXC800; Beckman Coulter, USA). 
Experimental data were subjected to statistical analyses with IBM SPSS Statistics for Windows, version 19.0 (IBM Corp., USA). Experimental data were expressed as mean \pm standard deviation. The basic data, energy metabolism indices, and liver functions in each group were analyzed with independent sample $t$-tests. Difference analysis was performed based on the indicator concentrations. Pearson's correlation coefficients were calculated to determine the relationships among the plasma NEFA, GLU, liver function indices, plasma BHBA levels, and ketosis in dairy cows from the prepartum and postpartum groups.

The establishment of two logistic models (Model I was the energy negative balance indicator model containing NEFA and GLU, and the Model II included liver function indicators such as AST and ALT) was then used to gradually screen the energy negative balance risk factors associated with ketosis and the abnormal risk factors of liver function. Finally, ROC analysis was used to determine the diagnostic effect and cut-off value. The BHBA was considered a continuous result.

\section{RESULTS}

Table 1 shows that the body condition score (BCS) of the prepartum and postpartum cows were significantly different $(\mathrm{P}=0.019)$. Differences in plasma BHBA $(\mathrm{P}=0.000)$, NEFA $(\mathrm{P}=0.000)$, and GLU $(\mathrm{P}=0.000)$ were also significant. NEFA increased significantly in dairy cows postpartum, while GLU and BCS decreased significantly. Subclinical ketosis developed postpartum in $42.25 \%$ of cows.

Table 1. Comparison of energy metabolism indices and subclinical ketosis incidence

\begin{tabular}{lcc}
\hline \multicolumn{1}{c}{ Variable } & Prepartum $(\mathrm{n}=63)$ & Postpartum $(\mathrm{n}=63)$ \\
\hline No & 0 & 30 \\
Subclinical ketosis incidence $(\%)$ & 0 & 42.25 \\
BCS & $2.81 \pm 0.38^{\mathrm{a}}$ & $2.65 \pm 0.34^{\mathrm{b}}$ \\
BHBA (mmol/L) & $0.43 \pm 0.14^{\mathrm{A}}$ & $1.65 \pm 1.30^{\mathrm{B}}$ \\
NEFA (mmol/L) & $0.29 \pm 0.22^{\mathrm{A}}$ & $0.69 \pm 0.37^{\mathrm{B}}$ \\
GLU (mmol/L) & $3.87 \pm 0.37^{\mathrm{A}}$ & $3.03 \pm 0.57^{\mathrm{B}}$ \\
\hline
\end{tabular}

N.B. Different uppercase letters in the table indicate significant differences at $\mathrm{P}<0.01$ and different lowercase letters indicate significant differences at $\mathrm{P}<0.05$. The same letter or no letter indicates that the difference is not significant at $\mathrm{P}>0.05$. $\mathrm{BCS}=$ body condition score, $\mathrm{BHBA}=\beta$-hydroxybutyric acid, NEFA=non-esterified fatty acids, GLU=blood glucose.

As shown in Table 2, there were significant differences in prepartum and postpartum levels of AST $(\mathrm{P}=0.000)$, AST/ALT $(\mathrm{P}=0.000)$, TBIL $(\mathrm{P}=0.001)$, DBIL $(\mathrm{P}=0.000)$, TP $(\mathrm{P}=0.000)$, GLO $(\mathrm{P}=0.000)$, and $\mathrm{A} / \mathrm{G}$ in cow plasma $(\mathrm{P}=0.000)$, and serum IBIL $(\mathrm{P}=0.017)$. Among them, AST,
AST/ALT, TBIL, DBIL, IBIL, TP, and GLO were significantly increased in postpartum dairy cows, while $\mathrm{A} / \mathrm{G}$ decreased significantly in prepartum cows. There were no significant differences in the plasma ALT $(P=0.269)$ and $\operatorname{ALB}(P=0.274)$ levels between groups.

Table 2. Liver function indicators of prepartum and postpartum dairy cows

\begin{tabular}{lcc}
\multicolumn{1}{c}{ Variables } & Prepartum $(\mathrm{n}=63)$ & Postpartum $(\mathrm{n}=63)$ \\
\hline AST $(\mathrm{U} / \mathrm{L})$ & $70.37 \pm 20.77^{\mathrm{A}}$ & $113.20 \pm 41.92^{\mathrm{B}}$ \\
ALT $(\mathrm{U} / \mathrm{L})$ & $23.50 \pm 6.43$ & $22.39 \pm 4.73$ \\
AST/ALT & $3.00 \pm 0.99^{\mathrm{A}}$ & $5.16 \pm 1.80^{\mathrm{B}}$ \\
TBIL $(\mu \mathrm{mol} / \mathrm{L})$ & $2.20 \pm 1.34^{\mathrm{A}}$ & $4.15 \pm 3.38^{\mathrm{B}}$ \\
DBIL $(\mu \mathrm{mol} / \mathrm{L})$ & $1.01 \pm 0.59^{\mathrm{A}}$ & $2.27 \pm 1.35^{\mathrm{B}}$ \\
IBIL $(\mu \mathrm{mol} / \mathrm{L})$ & $1.19 \pm 0.84^{\mathrm{a}}$ & $1.88 \pm 2.19^{\mathrm{b}}$ \\
TP $(\mathrm{g} / \mathrm{L})$ & $66.90 \pm 14.35^{\mathrm{A}}$ & $75.58 \pm 5.61^{\mathrm{B}}$ \\
ALB $(\mathrm{g} / \mathrm{L})$ & $35.54 \pm 7.88^{\mathrm{A}}$ & $34.35 \pm 3.96$ \\
GLO $(\mathrm{g} / \mathrm{L})$ & $31.35 \pm 8.86^{\mathrm{A}}$ & $41.24 \pm 7.18^{\mathrm{B}}$ \\
A/G & $1.14 \pm 0.35^{\mathrm{A}}$ & $0.87 \pm 0.20^{\mathrm{B}}$ \\
\hline
\end{tabular}

N.B. Different uppercase letters in the table indicate significant differences at $\mathrm{P}<0.01$ and different lowercase letters indicate significant differences at $\mathrm{P}<0.05$. The same letter or no letter indicates that the difference is not significant at $\mathrm{P}>0.05 \mathrm{AST}=$ aspartate aminotransferase, ALT=alanine aminotransferase, $\mathrm{TBIL}=$ total bilirubin, $\mathrm{DBIL}=\mathrm{direct}$ bilirubin, $\mathrm{IBIL}=$ indirect bilirubin, $\mathrm{TP}=$ total protein, $\mathrm{ALB}=$ albumin, $\mathrm{GLO}=$ globulin, $\mathrm{A} / \mathrm{G}=$ albumin/globulin ratio. 
Pearson's correlation coefficient analysis of basic cow data, energy metabolism indicators, and the correlation between cow liver function indicators and ketosis is presented in Table 3. The BCS ( $\mathrm{R}=-$ $0.19, \quad \mathrm{P}=0.04$ ) was significantly negatively correlated with ketosis. Plasma levels of GLU $(\mathrm{R}=-0.21, \mathrm{P}=0.03)$ and $\mathrm{A} / \mathrm{G}(\mathrm{R}=-0.21, \mathrm{P}=0.03)$ were significantly negatively correlated with ketosis. Plasma NEFA $(\mathrm{R}=0.45, \mathrm{P}=0.00)$, AST $(\mathrm{R}=0.57, \mathrm{P}=0.00)$, AST/ALT $(\mathrm{R}=0.49, \mathrm{P}=0.00)$, TBIL ( $\mathrm{R}=0.40, \mathrm{P}=0.00)$, DBIL $(\mathrm{R}=0.42, \mathrm{P}=0.00)$, IBIL $(\mathrm{R}=0.37, \mathrm{P}=0.00)$, TP $(\mathrm{R}=0.26, \mathrm{P}=0.01)$, and GLO $\quad(\mathrm{R}=0.35, \quad \mathrm{P}=0.00)$ were significantly positively correlated with ketosis.

Table 3. Correlations between clinical data, energy metabolism indicators, liver function indicators, and subclinical ketosis in dairy cows

\begin{tabular}{|c|c|c|}
\hline Variable & Average value $(n=126)^{1}$ & Correlation with BHBA levels \\
\hline BSC & $2.93 \pm 0.37$ & $\mathrm{R}=-0.19^{*}, P=0.04$ \\
\hline Glu (mmol/L) & $3.80 \pm 1.96$ & $\mathrm{R}=-0.21^{*}, P=0.03$ \\
\hline NEFA (mmol/L) & $0.46 \pm 0.33$ & $\mathrm{R}=0.45^{* *}, P=0.00$ \\
\hline AST (U/L) & $91.30 \pm 35.42$ & $\mathrm{R}=0.57 * *, P=0.00$ \\
\hline $\operatorname{ALT}(\mathrm{U} / \mathrm{L})$ & $22.76 \pm 5.48$ & $\mathrm{R}=0.06, P=0.54$ \\
\hline AST/ALT & $4.10 \pm 1.75$ & $\mathrm{R}=0.49 * *, P=0.00$ \\
\hline TBIL $(\mu \mathrm{mol} / \mathrm{L})$ & $3.25 \pm 3.12$ & $\mathrm{R}=0.40 * *, P=0.00$ \\
\hline $\mathrm{DBIL}(\mu \mathrm{mol} / \mathrm{L})$ & $1.49 \pm 1.31$ & $\mathrm{R}=0.42 * *, P=0.00$ \\
\hline IBIL $(\mu \mathrm{mol} / \mathrm{L})$ & $1.76 \pm 1.88$ & $\mathrm{R}=0.37 * *, P=0.00$ \\
\hline $\mathrm{TP}(\mathrm{g} / \mathrm{L})$ & $70.07 \pm 11.50$ & $\mathrm{R}=0.26^{* *}, P=0.01$ \\
\hline $\operatorname{ALB}(g / L)$ & $35.32 \pm 6.25$ & $\mathrm{R}=-0.01, P=0.88$ \\
\hline GLO (g/L) & $34.74 \pm 8.72$ & $\mathrm{R}=0.35^{* *}, P=0.00$ \\
\hline $\mathrm{A} / \mathrm{G}$ & $1.05 \pm 0.30$ & $\mathrm{R}=-0.21^{*}, P=0.03$ \\
\hline
\end{tabular}

Note: $* * \mathrm{P}<0.01, * \mathrm{P}<0.05$, and absence of $*$ indicates that the difference is not significant $(\mathrm{P}>0.05) .{ }^{(1)} \mathrm{n}=126$ is the sum of 63 blood samples in the prenatal group and 63 blood samples in the postnatal group.

The correlation analysis in Table 3 did not explain the predictive and causal nature of these indicators for postpartum ketosis in dairy cows. Therefore, two binary logistic regression models were established to simulate the predictability of the above indicators for ketosis. The models included NEFA and GLU energy balance indicators, and the 10 liver function indicators (AST, ALT, AST/ALT, TBIL, DBIL, IBIL, TP, ALB, GLO, and $\mathrm{A} / \mathrm{G})$.

The model results showed that the NEFA, GLU, and AST indicators could be used to predict ketosis. NEFA combined with GLU had the best fit and predictive effect for ketosis, which can be used as a standard for evaluation of the postpartum ketosis population. As an indicator of liver function related to ketosis, AST also had a good predictive effect for ketosis. This indicated that liver injury could increase the risk of developing ketosis, and AST can be an early warning indictor of ketosis.
Table 4 shows the cut-off values, sensitivity, and specificity of prepartum ketosis warning indicators and their respective standard errors, positive likelihood ratios, and area under the curve. The best cut-off values determined by calculation of the Youden index were AST $>68.0$ $\mathrm{U} / \mathrm{L}, \mathrm{GLU}<3.97 \mathrm{mmol} / \mathrm{L}, \mathrm{NEFA}>0.27 \mathrm{mmol} / \mathrm{L}$, $\mathrm{BHBA}>0.43 \mathrm{mmol} / \mathrm{L}$, and $\mathrm{BCS}>2.88$. The corresponding sensitivity and specificity for AST was $57.1 \%$ and $76.5 \%$, respectively, $64.3 \%$ and $88.2 \%$ for GLU, $64.3 \%$ and $70.6 \%$ for NEFA, $78.6 \%$ and $94.1 \%$ for BHBA, and $50.0 \%$ and $70.6 \%$ for BSC. Table 4 and Figure 1 show that the indicators had different degrees of ketosis diagnostic ability. Therefore, plasma AST $>68.0$ $\mathrm{U} / \mathrm{L}, \mathrm{GLU}<3.97 \mathrm{mmol} / \mathrm{L}, \mathrm{NEFA}>0.27 \mathrm{mmol} / \mathrm{L}$, $\mathrm{BHBA}>0.43 \mathrm{mmol} / \mathrm{L}$, and $\mathrm{BCS}<2.88$ were selected as the cut-off values for prepartum cow ketosis. 
Table 4. Threshold value, sensitivity, specificity, standard error, positive likelihood ratio, and area under the ROC curve for BCS, NEFA, AST, GLU, and BHBA for the diagnosis of subclinical ketosis

\begin{tabular}{|c|c|c|c|c|c|c|c|}
\hline Variable & $\begin{array}{c}\text { Threshold } \\
\text { value }\end{array}$ & $\begin{array}{c}\text { Sensitivity } \\
(\%)\end{array}$ & $\begin{array}{c}\text { SE } \\
\text { (Sensitivity } \\
\%) \\
\end{array}$ & $\begin{array}{c}\text { Specificity } \\
(\%)\end{array}$ & $\begin{array}{c}\mathrm{SE} \\
\text { (specificity } \\
\%)\end{array}$ & $+\mathrm{LR}^{\mathrm{a}}$ & AUC \\
\hline BCS & 2.88 & 50.0 & 13.36 & 70.6 & 10.74 & 1.70 & $\begin{array}{c}0.624, \\
P=0.242\end{array}$ \\
\hline $\begin{array}{l}\text { AST } \\
(\mathrm{U} / \mathrm{L})\end{array}$ & 68.0 & 57.1 & 13.23 & 76.5 & 9.99 & 2.43 & $\begin{array}{c}0.647, \\
P=0.165\end{array}$ \\
\hline $\begin{array}{c}\text { GLU } \\
(\mathrm{mmol} / \mathrm{L})\end{array}$ & 3.97 & 64.3 & 12.80 & 88.2 & 7.60 & 5.45 & $\begin{array}{c}0.763, \\
P=0.013\end{array}$ \\
\hline $\begin{array}{c}\text { NEFA } \\
(\mathrm{mmol} / \mathrm{L})\end{array}$ & 0.27 & 64.3 & 12.80 & 70.6 & 10.74 & 2.19 & $\begin{array}{c}0.721, \\
P=0.037\end{array}$ \\
\hline $\begin{array}{c}\text { BHBA } \\
(\mathrm{mmol} / \mathrm{L})\end{array}$ & 0.43 & 78.6 & 10.96 & 94.1 & 5.55 & 13.32 & $\begin{array}{c}0.855, \\
P=0.001\end{array}$ \\
\hline
\end{tabular}

$+\mathrm{LR}=$ positive likelihood ratio, $\mathrm{AUC}=$ area under the $\mathrm{ROC}$ curve.

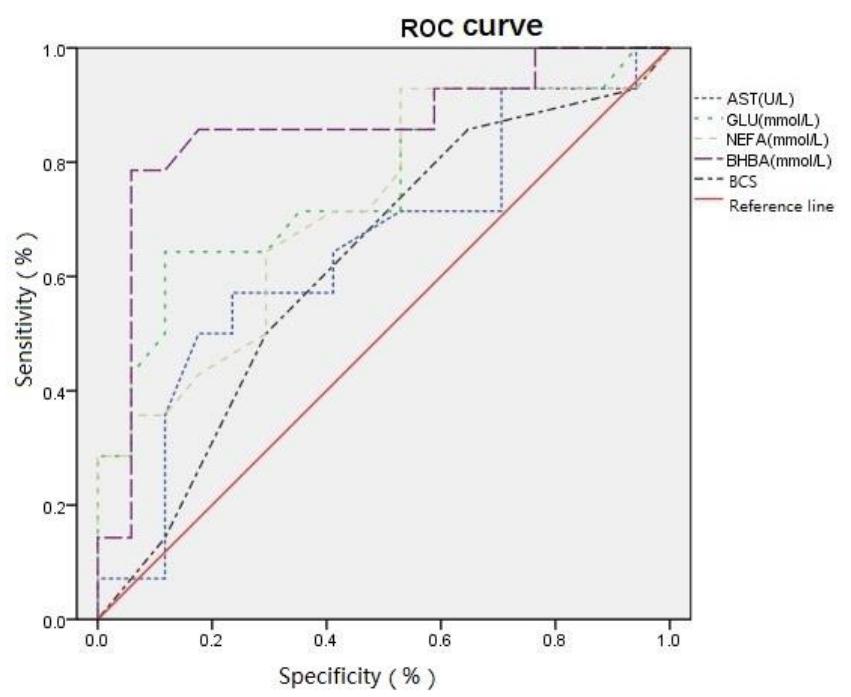

Figure 1. The area under the ROC curve of AST, GLU, NEFA, BHBA and BCS in experimental dairy cow plasma.

Note: AST=aspartate aminotransferase, GLU=blood glucose, NEFA=non-esterified fatty acids, BHBA= $\beta$ hydroxybutyric acid, BCS=body condition score. AST > 68.0 U/L, GLU < 3.97mmol/L, NEFA > 0.27mmol/L, BHBA $>0.43 \mathrm{mmol} / \mathrm{L}$, and BCS $<2.88$ were selected as the cut-off values for prepartum cow subclinical ketosis.

\section{DISCUSSION}

Ketosis is a metabolic disease that often occurs in high yielding dairy cows (Viña et al., 2016). In high yield cattle herds in China, the incidence of subclinical ketosis is higher and tends to increase annually (Mulligan et al., 2006; Xu et al., 2016). Subclinical ketosis is difficult to detect, and thus it is often overlooked in dairy ranch management. Therefore, it is necessary to select some indicators with high sensitivity and specificity, low cost, and simple detection to evaluate the condition of prepartum cows in order to reduce the incidence of postpartum ketosis.

Blood GLU and blood ketone levels are important indicators for diagnosing cow ketosis. Elevated ketone bodies and decreased blood GLU are the pathological basis for the occurrence of ketosis (Ingvartsen, 2006). BHBA is the main circulating ketone body in the blood of cows with ketosis, and is relatively stable in whole blood, plasma, serum, 
and even in vitro (Duffield, 2000; Herdt, 2000). In the present study, plasma BHBA $\geq 1.2 \mathrm{mmol} / \mathrm{L}$ was used as the diagnostic criteria for subclinical ketosis in dairy cows (Ospina et al., 2010), and the incidence of ketosis in prepartum and postpartum cows was analyzed. The results showed that the incidence of ketosis in postpartum cows was $42.25 \%$, markedly higher than the reported incidence of ketones in other countries (15-30\%) (Jeong et al., 2017). At the same time, the energy balance of the pre- and post-experimental dairy cows was tested, and the results showed that the levels of BHBA and NEFA increased significantly postpartum, while GLU levels were significantly lower prepartum.

Subclinical ketosis cows have severe NEB. Adipose tissue lipid mobilization is an important adaptation method for cows to meet their energy needs (Berge and Vertenten, 2014). Excessive lipid mobilization produces a large amount of fatty acids. When fatty acids enter the liver with the blood, they disrupt liver metabolism and damage liver function. Liver-specific enzymes ALT and AST exist in the cytoplasm or mitochondria of various organ cells, and have the highest activity in the liver, heart muscle, and skeletal muscle. The increase in these enzymes in the blood is mostly associated with liver damage. The AST of healthy adult cows is 78.00-132.00 U/L (Ingvartsen, 2006).

The average value of AST for prepartum cows in this study was $70.37 \mathrm{U} / \mathrm{L}$, comparable to that reported by Moallem et al. (2004). The average AST of postpartum dairy cows reached 113.2 $\mathrm{U} / \mathrm{L}$, which was significantly higher than that of prepartum cows. AST mainly exists in the mitochondria. When liver disease is acute, its elevation is lower than that of ALT, AST/ALT<1.0; when liver disease is aggravated, or in the event of chronic diseases such as hepatitis and cirrhosis, AST will increase significantly (Xia et al., 2010). In the present study, the average plasma AST level in postpartum dairy cows reached $113.20 \mathrm{U} / \mathrm{L}$, indicating that they had a certain degree of liver damage; therefore, elevated plasma AST was associated with ketosis.

The main source of IBIL is senescent red blood cells, usually formed by the degradation of hemoglobin in the spleen, liver, and bone marrow, which accounted for $70 \%-80 \%$ of TBIL in the blood (Kew, 2000). Hepatocytes ingest IBIL through a series of enzymatic reactions in the smooth endoplasmic reticulum to form DBIL, which is soluble in water, easily soluble in bile, and excreted into the intestinal tract. Elevated levels of TBIL, DBIL, and IBIL postpartum indicated that bile excretion disorders were related, thereby indicating a certain degree of liver damage.

By analyzing the differential indicators in the blood of prepartum and postpartum cows, the ROC analysis curve was used to define the warning values of NEFA, GLU, and BHBA in the prepartum plasma of dairy cows. The NEFA, GLU, and BHBA warning values were $0.27 \mathrm{mmol} / \mathrm{L}, \quad 3.97 \mathrm{mmol} / \mathrm{L}$, and $0.43 \mathrm{mmol} / \mathrm{L}$, respectively. The NEFA warning value was similar to that reported in a previous study $(0.26 \mathrm{mmol} / \mathrm{L})$, while the GLU warning value was higher than that reported $(2.26 \mathrm{mmol} / \mathrm{L})$ (Ardavan et al., 2011). The BHBA warning value was significantly lower than that reported in late pregnancy cows $(0.6 \mathrm{mmol} / \mathrm{L})$ by Whitaker (1997). These discrepancies may be related to the difference in detection of postpartum days and average blood index of cows under different feeding management between studies, it may also be related to different detection methods.

In conclusion, the plasma levels of AST $>68.0$ $\mathrm{U} / \mathrm{L}, \mathrm{GLU}<3.97 \mathrm{mmol} / \mathrm{L}, \mathrm{NEFA}>0.27 \mathrm{mmol} / \mathrm{L}$, and BHBA $>0.43 \mathrm{mmol} / \mathrm{L}$ reported in prenatal dairy cows in a dairy farm in Heilongjiang may indicate high susceptibility of subclinical ketosis postpartum. A BSC $<2.88$ appeared to be an early warning indicator of ketosis. This may provide a basis for early nutrition regulation of ketosis.

\section{ACKNOWLEDGMENTS}

We thank International Science Editing (http://www.internationalscienceediting.com) for editing this manuscript. This study was funded by the following projects: Study on Prevention and Control of Common Diseases in Livestock and Poultry (2017YFD0502200), Demonstration Project for Poverty Alleviation of Standardized Aquaculture Industry (ZY17C08), and Research and Demonstration of Key Technologies for Comprehensive Prevention and Control of Major Reproductive Disorders of Dairy Cows in Heilongjiang Reclamation Area (HKKY190302). The study protocol was approved by the Ethics 
Committee on the Use and Care of Animals of Heilongjiang Bayi Agricultural University (Daqing, China). The study was approved by the farm owner and all animal experiments were conducted according to the International Guiding Principles for Biomedical Research. The protocol was approved by the Committee on the Ethics of Animal Experiments of the Heilongjiang Bayi Agricultural University.

\section{REFERENCES}

ARDAVAN, N.A.; SAEED, N.; ABBAS, R.G. et al. Prevalence of subclinical ketosis in dairy cattle in the Southwestern Iran and detection of cutoff point for NEFA and glucose concentrations for diagnosis of subclinical ketosis. Prev. Vet Med., v.100, p.38-43, 2011

BERGE, A.; VERTENTEN, G. A field study to determine the prevalence, dairy herd management systems, and fresh cow clinical conditions associated with ketosis in western European dairy herds. J. Dairy Sci., v.97, p.2145-2154, 2014.

CARRIER, J.; STEWART, S. Evaluation and use of three cowside tests for detection of subclinical ketosis in early postpartum cows. J. Dairy Sci., v.87, p.37253735,2004

DUFFIELD, T. Subclinical ketosis in lactating dairy cattle. Vet. Clin. N. Am. Food Anim. Pract., v.16, p.231253, 2000.

GATHERCOLE, L.L.; MORGAN, S.A.; TOMLINSON, J.W. Hormonal regulation of lipogenesis. Vitam. Horm., v.91, p.1-27, 2013.

HERDT, T.H. Variability characteristics and test selection in herdlevel nutritional and metabolic profile testing: metabolic disorders of ruminants. Vet. Clin. N. Am. Food Anim. Pract., v.16, p.387-403, 2000.

INGVARTSEN, K.L. Feeding and management related diseases in the transition cow: Physiological adaptations around calving and strategies to reduce feeding-related diseases. Anim. Feed Sci. Technol., v.126, p.175-213, 2006

JEONG, J.K.; CHOI, I.S.; MOON, S.H. et al. Effect of two treatment protocols for ketosis on the resolution, postpartum health, milk yield, and reproductive outcomes of dairy cows. Theriogenology, v.106, p.5359, 2017.
JEZEK, J.; CINCOVIC, M.R.; NEMEC, M. et al. Betahydroxybutyrate in milk as screening test for subclinical ketosis in dairy cows. Pol. J. Vet. Sci., v.20, p.507-512, 2017.

KEW, M.C. Serum aminotransferase concentration as evidence of hepatocellular damage. Lancet, v.355, p.591-592, 2000.

MCART, J.A.A.; NYDAM, D.V.; OETZEL, G.R. Epidemiology of subclinical ketosis in early lactation dairy cattle. J. Dairy Sci., v.95, p.5056-5066, 2012.

MOALLEM, U.; BRUCKENTAL, I.; SKLAN, D. Effect of feeding pregnant and non lactating dairy cows a supplement containing a high proportion of nonstructureal carbohydrates on postpartum production and peripartum blood metabolites. Anim. Feed Sci. Technol., v.116, p.185-195, 2004.

MULLIGAN, F.J.; O'GRADY, L.; RICE, D.A. et al. A herd health approach to dairy cow nutrition and production diseases of the transition cow. Anim. Reprod. Sci., v.96, p.331-353, 2006

OSPINA, P.A.; NYDAM, D.V.; STOKOL, T. et al. Evaluation of nonesterified fatty acids and $\beta$ hydroxybutyrate in transition dairy cattle in the Northeastern United States: critical thresholds for prediction of clinical diseases. J. Dairy Sci., v.93, p.546-554, 2010.

VANHOLDER, T.; PAPEN, J.; BEMERS, R. et al. Risk factors for subclinical and clinical ketosis and association with production parameters in dairy cows in the Netherlands. J. Dairy Sci., v.98, p.880-888, 2015.

VIÑA, C.; FOUZ, R.; CAMINO, F. et al. Study on some risk factors and effects of bovine ketosis on dairy cows from the Galicia region (Spain). J. Anim. Physiol. Anim. Nutr., v.101, p.835-845, 2016.

WHITAKER, D.A. Interpretation of metabolic profiles in dairy cows. Cattle Pract., v.5, p. 57-60, 1997.

XIA, C.; WANG, Z.; LIU, G.W. et al. Changes of plasma metabolites, hormones, and mRNA expression of liver PEPCK- $\mathrm{C}$ in spontaneously ketotic dairy cows. Asian Aust. J. Anim. Sci., v.23, p.47-51, 2010.

XU, C.; XU, Q.; CHEN, Y.; YANG, W.; XIA, C. et al. FGF-21: promising biomarker for detecting ketosis in dairy cows. Vet. Res. Commun., v.40, p.49-54, 2016. 